\title{
$\mathrm{CAI}$ 프로그램의 활용에 따른 학습 효과 분석
}

\author{
조 해 곤 ${ }^{\dagger}$ 정 재 열 ${ }^{\dagger}$.노 영 욱 ${ }^{\dagger \dagger}$.최 재 혁 ${ }^{\dagger \dagger}$
}

요 약

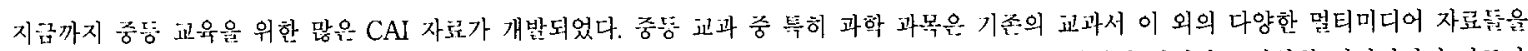
수업에 많이 활용한다. 과학 과목 충 생물의 생태와 구소 및 성분에 대한 기초 지식을 효율적으로 습듭시키기 위해서는 다양한 멀티미디어 자코가

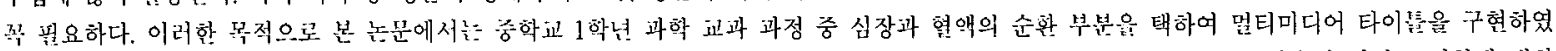
다. 하시만 기존의 선행 연구들은 CAI 프로그램을 개밖하는 데에만 중점을 두었고, 이러한 CAI 프로.그램돈이 실제로 학습에 미치는 영향에 대한 실중적인 분석 결과들은 거의 제시하지 않았다. 따라서 본 연구에서는 개발한 CAI 프로그램의 활용 유부에 따라 학숩에 미치는 영향에 대한 분석 방법과 고 결과롤 제시하였고, 또한 앞으로 멀티미디어 CAI론 활용한 수업의 효율성을 극대화할 수 있는 방안을 제시하였다.

\section{Analysis of Learning Effects on Utilization of CAI Program}

\author{
Hae-Gon $\mathrm{Cho}^{\dagger} \cdot$ Jae-Yeul Chung ${ }^{\dagger \dagger} \cdot$ Young-Ung Lho $^{\dagger \dagger} \cdot$ Jae-Hyuk Choi ${ }^{\dagger \dagger}$
}

\begin{abstract}
Many CAI materials have been developed for middle school education. Among subjects in middle school education curricula, various multimedia materials are used in science subjects. Especially, those materials are necessary to teach basic knowledge of the environment, structure and components of animal. Thus, we implemented a multimedia title for a chapter of heart and blood circulation from first year science subject in middle school curricula. Most previous researches mainly focused on the development of CAI programs, but did not suggest the analysis result of impact using those CAI programs. In this paper, we presented the analysis method of impact and the result, but also suggested a way to improve effectiveness of teaching in a class.
\end{abstract}

키워드 : 멀티미디어, CAI, WBI, 컵퓨터교육, 학습효과분석

\section{1. 서 론}

오늘날의 교수 학습 과정에서 컴퓨터롤 직접 활용하는 즉, 일련의 학습 과정이 컴퓨터에 의해 진행되는 교수 - 학습 방 법적 활용이 상당한 비중을 차지하고 있다. 따라서 지금까지 중등 교육을 위해 다양한 과목의 많은 CAI(Computer Aided Instruction) 및 WBI(Web Based Instruction) 교육용 프로 그램이 개발되었다. 중등 교과목 중 톡히 과학 과목은 기존의 교과서가 텍스트 위주이기 때문에 다양한 자료(챠트, 비디오 등)둘을 수업에 많이 활용하였으나, 최근에 돓어서는 컴퓨터 의 특성과 기능을 최대한 살려 학습에 활용할 수 있도록 구 현된 멀티미디어 CAI나 WBI 교육용 프로그램울 과학 수업 에 활용하려는 경향이 많다[1]. 톡히 멀티미대어 $\mathrm{CAI}_{2}^{2}$ 영 영상 이나 화상 또는 음향과 같은 고밀도의 정보 전달 매체롤 사

$\dagger$ 정 외 원 : 북산 망미중학교 교사

†† 정 회 원 : 신라대학교 컴퓨터교육과 iㅛㅅㅜ

t†† 옹신회원 : 신라대학교 컴퓨터교육과 교수

논몬접수 : 2001 년 9 원 10 일, 심사완료 : 2001 년 12 원 18일
용하여 정보 전달 효과가 높으며, 수업의 주체가 교사인 동시 에 대화 방식이므로 적시에 학습자들이 원하는 정보롤 전달 해 출 수 있는 장점을 가지고 있다[2,3]. 본 연구에서는 중학 교1 1학년 과학 교과 중 심장과 혈액의 순환 부분에 대한 멀티 미디어 CAI 프로그램을 구현하였다.

기존의 선행 연구들은 이러한 멀티미디어 CAI 프로그램이 나 윕 기반 코스웨어의 구현에 대한 연구나[4-13], 구현 이후 에 간단한 설문 조사나 기존 프로그램과의 비교를 통해 구현 한 프로그램의 효율성울 제시하는 정도의 연구가 대부분이었 다[14, 15]. 이들 프로그램을 실제 수업에 활용한 후, 설문 분 석한 연구로 멀티미디어 CAI 프로그램에 대한 기존의 설문 분석 연구는 거의 없으며, 웹 기반 코스웨어에 대한 설문 조 사롫 통한 분석이 이루어진 연구 또한 많지 않다. 웹 기반 코 스웨어에 대한 설문 분석을 행한 연구는 다음과 같다.

반승록은 83명의 학생을 대상으로 학습 집단을 웹을 통한 가상 실험 수업 집단과 전통 실험 수업 집단으로 나두고, 이 돌 실험 집단에 대한 수업 효과롤 사전 사후 검사를 통해 조 
사하여 가상 수업 집단의 성적이 더 좋다는 결론의 도출과 설문지를 통한 가상 실험 수업의 호과를 제시하였다[16].

최정임은 12 명의 대학원생둘을 대상으로 웹 기반 수업에서 나타난 상호 작용의 패턴과 상호 작용에 영향을 주는 요소에 대한 분석과 상호 작용이 학습자의 성취와 수업 태도에 미친 영향을 탐구하여 효과적인 교수 전략을 제시하였다[17].

송문석은 60 명의 학생을 대상으로 실험 집단과 통제 집단에 대한 학력 평가와 웹 기반 수업의 효과에 대한 설문 조사를 통 해 웹 기반 수업이 교육적 효과가 높음을 제시하였다[18].

박미정은 247 명의 학생들을 대상으로 면대면 교실 수업과 웹 기반 수업을 병행하여 소그롭별로 문제를 웹을 통해 해결 하는 웹 기반 문제 해결 학습 환경을 개발하는데 목적을 두 었고, 이를 설문 평가를 통해 분석하였다[19].

위에서 제시된 것처럼 기존의 설문 조사를 통한 연구의 대부 분은 코스웨어를 개발한 후, 이들 코스웨어를 이용한 수업의 효 율성만을 강조하였고, 이들 코스웨어가 실제 학습 효과에 미치 는 영향에 대한 실증적인 분석 결과와 이률 바탕으로 효율적인 수업 활용 방안을 제시한 연구는 지금까지 발표되지 않았다.

따라서 본 연구에서는 구현한 멀티미디어 CAI 프로그램을 직접 수업에 활용한 후, 학습에 미치는 영향에 대한 효과를 세밀히 분석하고 그 결과를 제시한다. 그리고 분석 결과의 정 확성을 보장하기 위해 평가 집단을 $\mathrm{CAI}$ 수업 집단과 강의식 수업 집단으로 나누어 평가와 설문 조사를 행한 후, 다시 이 들 집단에 대해 수업 형태를 바꾸어 평가와 설문 조사를 다 시 시행하는 방법을 택하였다. 이러한 분석 결과를 토대로 앞 으로 멀티미디어 CAI 프로그램을 활용한 수업의 효과를 극 대화할 수 있는 수업 방법을 제안한다.

\section{2. 멀티미디어 CAl 프로그램 설계 및 구현}

교과서만으로 학습 능력을 높이는 것보다는 교단 선진화 기자재를 활용한 멀티미디어 자료를 참고하여 관련된 사진, 동영상, 애니메이션, 소리를 효율적으로 제작해 놓은 $\mathrm{CD}$ 타 이틀을 이용하면 보다 효과적인 학습 능력을 높일 수 있다. 즉, 개별 학습이 가능하여 학습자 스스로 시간에 구애받지 않 고 언제나 학습할 수 있으며, 부족한 부분만을 골라 집중적으 로 학습할 수 있다. 또한 교사는 다양한 멀티미디어 자료를 학생들에게 제시하면서 부가적인 설명을 할 수 있어 의사 전 달과 학습 의욕을 향상시킬 수 있다[13].

본 연구에서 멀티미디어 CAI 프로그램을 구현하기 위하여 멀티미디어 툴 북 5.0 , 나모 웹 에디터 3.0 , flash 3.0 과 같은 도구를 사용하였다.

멀티미디어 CAI 프로그램의 수업에 대한 효과 분석을 위해 본 연구에서 구현한 $\mathrm{CAI}$ 프로그램의 전체 메뉴는 (그림 1)과 같다. 전체 메뉴에서는 학습자가 학습 중에 길을 잃지 않고 제 대로 학습해 나갈 수 있도록 전체적인 학습 단원과 소단원에 대한 안내 및 학습 목표를 제시하고 있다.

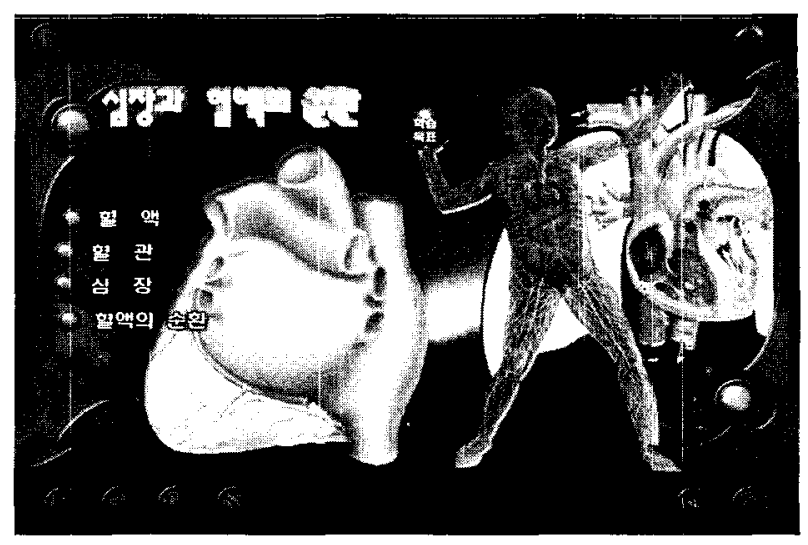

(그림 1) 학습내용 전체 메뉴 안내

(그립 2)는 전체 메뉴에서 심장을 클릭 하였을 때의 심장에 대한 학습 내용이 전개듸며, 핵심 정리, 단원 평가, 심화 보충 학습과 같이 단계별로 선택하도록 구성되어 있다.

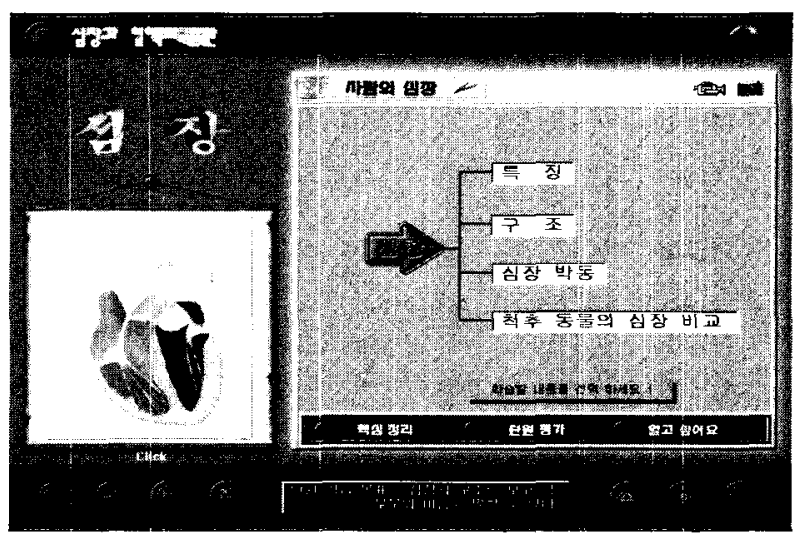

(그림 2) 학습 내용 전개

(그림 3)은 학습을 마치고 학습한 내용을 간단하게 피드백 하는 부분으로 연결되어 있다.

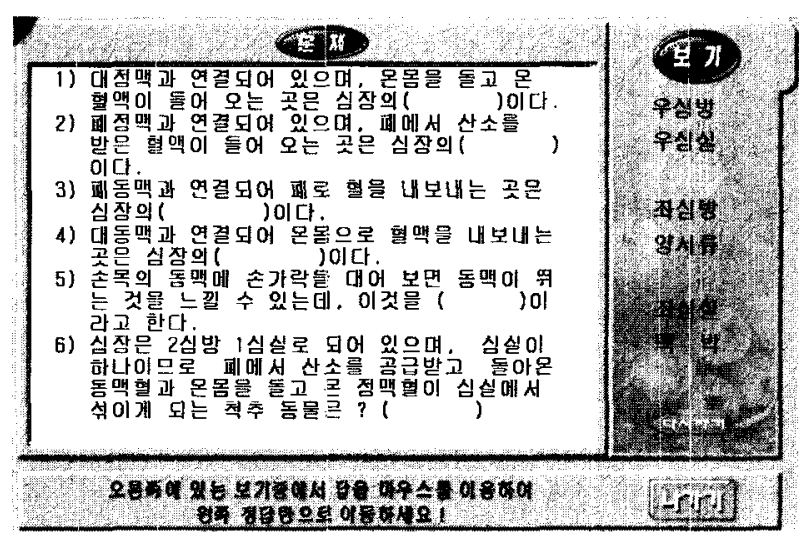

(그림 3) 단원평가 문제

구현한 CAI 프로그램은 멀티미디어 자료를 자유 자재로 연 결해 주논 하이퍼링크 7 능 동이 기술적 기초롤 이루며, 인간 
의 심장과 혈액 순환의 신비한 과정을 학습자기 쉽게 이해한 수 있도록 위의 그림과 같은 방식으로 전체가 구성되어 있다.

\section{3. 연구 방법}

\section{1 실험 대상}

본 연구의 실험을 위하여 부산광역시 S 중학교 1 학년 13 개 의 반 중에서 1 학기 중간고사 성적의 평균 점수가 6,7 등인 충 간에 속하는 2 개의 반을 선정하였고, 각각의 반은 남학생 19 명, 여학생 18 명으로 총 74 명 학생이 참여하였다. 이출 학생은 이 전에 컴퓨터롤 사용하여 수업을 받은 경헙이 여러 번 있어 본 실험의 대상 학생으로 적합하다고 판단된다.

\section{2 실험 설계}

본 연구는 섬계 닟 구현된 멀티미디어 CAI 프도기램의 수업 활용 유무에 따론 사실적 학습 효과에 미치눈 영향영 정확히 검증하기 위한 평가 방벏으로 평가지와 선번지폰 사 용하였다. 실험에 사용되는 멀티미디어 CAI 프로기랚의 질에 따라 분석 결과가 답리 나올 수 있으므로, 검증된 멇티미디어 CAI 프록ㄹ램을 사용하여야 한다. 본 연국에서 사용한 멀티미 디어 CAI 프로- $I$ 램은 부산광역시 교육청 주최 $\mathrm{S} / \mathrm{W}$ 공모전 에서 우수상을 받아 어 $\mathrm{L}$ 정도는 검정된 CAI 프로 1 랚이다.

본 연구에서 제시하는 설문 방법은 기존의 설문 조사 방법 과는 달리 2개의 설문 집단을 꾸성하고, 강의식 수업과 $\mathrm{CAI}$ 활용 수업을 뚜 집단에 대해 모두 시행한 후, 평가지와 설꾼 지롤 통해 평가와 분석 결과를 도출하는 방법이다. 즉, 집단 1 에 대해서는 먼저 순환기관 단원의 심장과 혈액의 순환 중 에서 심장에 대한 수업을 평소와 같이 강의식 수업을 진행한 후 1차 평가 검사와 1차 설문지 조사폴 시행하고, 그 다음 시 간에 $\mathrm{CAI}$ 롤 활용한 수업을 진행하고 2 차 평가 검사와 2차 섶 문지 조사롤 시행한다. 집단 2 에 대해서는 집단 1과는 반대의 형태로 먼저 CAI퐇 활용한 수업을 진행한 후 1차 평가 검사 와 1 차 설문지 조사롤 시행하고, 그 다음 시간에 강의식 수업 을 진행한 후 2 차 평가 검사와 2 차 설문지 조사롤 시행한다. 이를 도표로 나타내면 <표 1>과 같다.

\section{〈표 1〉 평가지와 설문지 시행 방법}

\begin{tabular}{|c|c|c|c|c|c|c|}
\hline 집단 & $\begin{array}{c}\text { 강의 방법 } \\
\quad 1\end{array}$ & $\begin{array}{c}1 \text { 차 } \\
\text { 평가검사 }\end{array}$ & $\begin{array}{c}1 \text { 차 } \\
\text { 설문:지조사 }\end{array}$ & \begin{tabular}{|c} 
강의방법 \\
2 \\
\end{tabular} & $\begin{array}{c}2 \text { 차 } \\
\text { 평가검사 }\end{array}$ & $\begin{array}{c}2 \text { 차 } \\
\text { 설 몬지조사 }\end{array}$ \\
\hline 1 & $\begin{array}{l}\text { 강의식 } \\
\text { 수업 }\end{array}$ & $\begin{array}{c}\text { 평가지 } \\
\text { A }\end{array}$ & 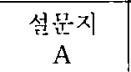 & $\begin{array}{c}\text { CAI확용 } \\
\text { 수업 }\end{array}$ & $\begin{array}{c}\text { 평가지 } \\
\mathrm{A}\end{array}$ & $\begin{array}{l}\text { 섬돈시니 } \\
C \\
C\end{array}$ \\
\hline 2 & $\begin{array}{c}\text { CAI홯용 } \\
\text { 수업 }\end{array}$ & $\begin{array}{c}\text { 평가지 } \\
\text { A }\end{array}$ & $\begin{array}{l}\text { 섬판지 } \\
\text { B }\end{array}$ & $\begin{array}{l}\text { 강의식 } \\
\text { 수업 }\end{array}$ & $\begin{array}{c}\text { 평가지 } \\
\text { A }\end{array}$ & 설 琶지 \\
\hline
\end{tabular}

<표 1>의 1,2 차 평가 검사는 1 개의 동일한 평가지롤 사 용하였다. 이렇게 동일한 평가롤 실시한 이유는 정확한 CAI 활용 수업의 효과롤 분석하기 위하여 1차 평가 결과롤 비표 하고 똑 같은 문제로 2차 평가 결과롤 비표하여 향상된 변 량을 분석합으로써 $\mathrm{CAI}$ 롤 활용한 수업이 학업 성취도에 미
치는 영향을 정확히 분석하기 위해서이다. 설문지는 모누 3가 지 종듄롤를 사용하였는데, 이는 강의식 수업을 받고 느낀 점과

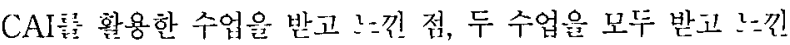
점을 종합하여 비료 본석하기 위합이다. 톡히 섧문지 $\mathrm{A}, \mathrm{B}$ 는 평봉 섧번가 강의식 및 CAI 활용 수업의 개별 설문으로 구성 되어 있다. 겅통 내용의 선문 먼항으로 멀티띠디어롤 할용한 수 업을 받아본 경헊을 물었고 느미 점을 -우선 순위로 질문하였다.

\section{3 실험 절차}

논 연 구의 실헊은 2001년 4월 26일부터 27일까지 2일에 걸쳐 심시하였다. 심헙대상자는 2 개 반으로 집단 1과 집단 2 로 거번하여 집단 1 은 강의식 수업을 1시간 먼서 싫시하고 나서 멉터미디어 CAI 프로그램을 활용한 수업을 1시간 실시하고, 집난 2는 덤티미디어 CAI 프로그랟을 활용한 수업을 먼저 1 시간 신시하고. 나서 강의식 수업을 1 시간 십시하였다. 실헊에 소오된 시간은 종 4시간으로, 고체적인 전차눈 다음가 같다

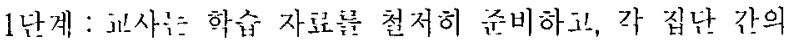

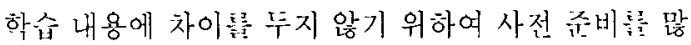
이 하였다.

2 난계 : 대상 집난 1에서는 겅통 설번-은 먼저 조사한 훗, 학습 에 필요한 케도와 인체 모형도를 즌 준비하고, 인반적으로 진행하는 강의식 수업(심장부분)을 30분 십시하였다.

3 단계 : 대상 집단 2 에서는 공톻 선문-을 먼저 조사한 훙, 본 연도에서 개발한 CAI 프로-그램(심장 부분)을 활용한 수업을 약 30 분 정도 실시하였다.

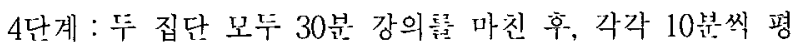
가와 설문지 $(A, B)$ 조사를 시행하였다.

5 단계 : 다음낧 대상 집단을 바꾸어 대상 집단 1 에서년 본 연 구에서 개밝한 멇터미디어롤 이용한 CAI 프로그램 (심장 부분)을 활용한 수업은 진행하였다.

6 단계 : 대상 집단 2 에서 대상 집단 1과 똑 갊은 강의식 수업 을 진행하였다.

7단계 : 두 집단 모두 30분 강의 를 마친 후, 각각 10분씨 평

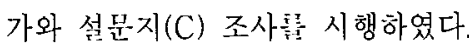

\section{4. 연구 결과 분석 및 해석}

\section{1 평가 검사 분석}

1차 평가 결과롤 비표하고 똑 같은 뚠제호 2차 평가 결과 의 향상된 변량을 분석하였다. 이는 CAI롤 환용한 수업이 학 업 성취는에 미치는 영향을 알아보기 위한 것으로, $=1$ 평가 검사 결과는 표 2>와 잩다.

<표 2>에서 집단 1 의 평가 검사 점수(강의식 수업)는 평 권은 68.38접이고, 집단 2 의 평가 검사 점수(CAI 홯용 수업) 는 70.81 점으로 집단 간의 평균 점수가 2.43 점으로 유의미한 차이가 나타났다. 하지만 집단 1 의 2 차 평가 검사 점수(강의 식-CAI)는 오히려 집단 2 의 2 차 평가 검사 점수(CAI 강의식) 보다 평뉸 1.35 점의 높게 나타났다. 이러한 변의 검사론 $100 \%$ 
신뢰할 수는 없다 하더라도, $\mathrm{CAI}$ 를 활용한 수업이 학업 성취 도에 있어서는 강의식 수업보다 조금 높은 것으로 분석된다. 이를 좀 더 구체적으로 분석하기 위해 평가 문항 별로 비교 분석하였으며, 이의 결과는 <표 $3>$ 과 같다.

〈표 2〉평가검사 결과표

\begin{tabular}{|c|c|c|c|c|}
\hline 집단 & $\begin{array}{c}\text { 강의식 수업 } \\
\text { 1차 } \\
\text { (집단 1) }\end{array}$ & $\begin{array}{c}\mathrm{CAI} \text { 수업 } \\
\text { 1차 } \\
\text { (집단2) }\end{array}$ & $\begin{array}{c}\text { 강의식-CAI } \\
\text { 2차 } \\
\text { (집단 1) }\end{array}$ & $\begin{array}{c}\mathrm{CAI-강-의식} \\
\text { 2차 } \\
\text { (집단 2) }\end{array}$ \\
\hline \hline 30점 & $\cdot$ & $\cdot$ & $\cdot$ & $\cdot$ \\
\hline 40 점 & 1 & 2 & 1 & 1 \\
\hline 50 점 & 4 & 1 & 2 & 1 \\
\hline 60 점 & 10 & 7 & 3 & 4 \\
\hline 70 점 & 12 & 12 & 3 & 3 \\
\hline 80 점 & 5 & 12 & 12 & 15 \\
\hline 90 점 & 5 & 3 & 7 & 7 \\
\hline 100 점 & $\cdot$ & $\cdot$ & 9 & 6 \\
\hline 충 점 & 2530 & 2620 & 3020 & 2970 \\
\hline 평 균 & 68.38 & 70.81 & 81.62 & 80.27 \\
\hline
\end{tabular}

주) 평가점사는 100 점 만점임.

〈표 3〉 문항별 평가 결과표

\begin{tabular}{|c|c|c|c|}
\hline 문 항 & 소 단 원 & 강의식 수업 & CAI활용 수업 \\
\hline \hline $1,2,3,4,5,6$ (각각 10 점) & 역 할 & 1500점 & 1710점 \\
\hline 7 (10점) & 명 칭 & 200점 & 270 점 \\
\hline 8 (20점) & 심화 내용 & 580 점 & 360 점 \\
\hline 9 (10점) & 구 조 & 250점 & 280 점 \\
\hline 총 점 & 5150 점 & 2530점 & 2620 점 \\
\hline 대상인원 & 총 74명 & 37 명 & 37 명 \\
\hline 평 규 & - & 68.38 & 70.81 \\
\hline
\end{tabular}

대부분 문항에서 $\mathrm{CAI}$ 활용한 수업이 점수가 높게 나왔으 나 심화내용 문항 8번 강의식 수업이 580 점, $\mathrm{CAI}$ 활용 수업 이 360 점으로 강의식 수업이 상당히 높게 나왔다. 8번 문항 은 “사람의 심장에 대한 설명이다. 옳지 않은 것은?"으로 9 개 의 평가 문항 중 가장 깊이 있는 심화 내용에 대한 문항이다. 이는 학습의 수준을 향상시킨 심화 학습에 대해서는 강의식 수업이 훨씬 효과적인 것으로 분석할 수 있다. 이를 좀 더 자 세히 분석하기 위해 문항 8번에 정답을 표시한 학생(강의식 29 명, $\mathrm{CAI}$ 활용 수업 18명)의 성적을 알아보았다. 성적이 상 위 $50 \%$ 에 속하는 18 명의 학생에 대해 강의식 수업을 받은 집단에서는 18 명 모두가, $\mathrm{CAI}$ 수업을 받은 집단에서는 14 명 만이 문항 8 을 맞혔고, 성적이 하위 $50 \%$ 에 속하는 학생 중 강의식 수업은 11 명, $\mathrm{CAI}$ 수업은 4 명만이 문항 8 을 맞힌 것 으로 조사되었다. 이는 $\mathrm{CAI}$ 활용 수업이 흥미와 이해롤 돕기 는 하지만, 심화 학습을 필요로 하는 수업에는 크게 학습에 영향을 미치지는 못하고, 오히려 강의식 수업이 심화 학습에 효과가 있는 것으로 분석되었다. 따라서 이에 대한 좀 더 정 확한 문항별 평가 분석에 대한 연구가 필요하다.

\section{2 설문지 분석}

설문지 분석은 먼저 강의식 수업을 받고 느낀 점과 $\mathrm{CAI}$ 를 활
용한 수업을 받고 느낀 점을 비교 분석하고, 다음어 두 수업을 모두 받고 느끼 점을 종합하여 비교 분석하였다. <표 4>는 본 실험에서 사용한 설문지 분류표로, 설문지 $\mathrm{A}, \mathrm{B}$ 의 공톧 문항 및 개별 문항과 설문지 $\mathrm{C}$ 의 개별 문항을 도표로 제시한 것이다.

〈표 4〉설문지 분석표

\begin{tabular}{|c|c|c|c|}
\hline 선돈지 & 수업 방법 & $\mathrm{A}, \mathrm{B}$ 공통 문항 & $\mathrm{A}, \mathrm{B}, \mathrm{C}$ 개별 문항 \\
\hline $\begin{array}{c}\text { 설몬지 } \\
\mathrm{A}\end{array}$ & 강의식 수업 & A-1.1, A-1.2 & $\begin{array}{l}A-2, A-3, A-4, A-5, \\
A-6\end{array}$ \\
\hline $\begin{array}{c}\text { 설문지 } \\
\mathrm{B}\end{array}$ & $\begin{array}{c}\text { CAI } \\
\text { 활용 수업 }\end{array}$ & B-1.1, B- 1.2 & $\begin{array}{l}\text { B-2, B-3, B-4, B-5, } \\
\text { B-6 }\end{array}$ \\
\hline \multirow{2}{*}{ 섫문지 } & 강의식-CAI & & \multirow{2}{*}{$\begin{array}{l}\mathrm{C}-1,2,3,4,5,6,7 \\
\quad 8,9\end{array}$} \\
\hline & $\mathrm{CAI}$ 강의식 & & \\
\hline
\end{tabular}

\subsection{1 설문지 $\mathrm{A}, \mathrm{B}$ 의 공통 설문 문항 분석}

공통 설문은 본 수업 이전에 실험 대상 학생들의 $\mathrm{CAI}$ 활 용 수업을 받아본 경험의 유무와 받은 시간을 조사하기 위한 2 개의 섞문으로 구성되어 있다.

CAI 황용 수업을 받은 적이 있는가의 설문에 대한 결과는 (그림 4)에서 나타난 바와 같이 $100 \%$ 의 모든 학생들이 멀티 미디어 CAI 타이틀을 활용한 수업을 받은 것으로 나타났 다. 이전에 받은 $\mathrm{CAI}$ 활용 수업 시간은 (그림 5)에서 10시간 14시간이 $72 \%(52$ 명 ), 5시간 9시간이 19\%(7명)로 나타났 다. 이는 대부분의 학생들이 CAI 타이틀을 이용현 수업을 5 시간 이상 받은 것으로 나타나, 본 연구의 설문을 제대로 평 가할 수 있을 것으로 생각된다.

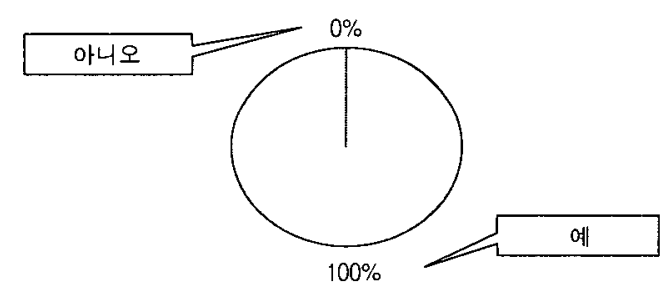

(그림 4) CAl 활용 수업을 받아본 경험 유무 (설문A-1.1, B-1.1합계)

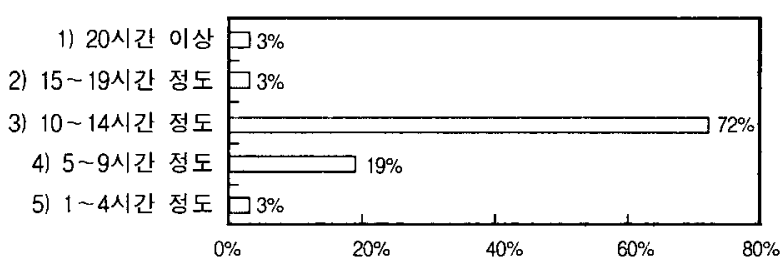

(그림 5) CAl 활용 수업 시간 분포도 (설문A-1.2, B-1.2 합계)

\section{2 .2 설문지 $\mathrm{A}, \mathrm{B}$ 의 개별 설문 문항 분석}

설문지 $\mathrm{A}, \mathrm{B}$ 의 개별 설문은 강의식 수업과 $\mathrm{CAI}$ 활용 수업의 학습 효과롤 분석하기 위하여 5가지 문항으로 구성되어 있다.

(그림 6)과 (그림 7)은 강의식 수업과 CAI 활용 수업만 받 은 후 선호도의 결과이고, (그림 8)는 강의식 수업과 CAI 활 
용 수업을 보두 밚은 후의 선호도 결과이다. 강의시 수업을 받은 집단의 $\mathrm{CAI}$ 활용 수업 선호도는 $81 \%$, 실제로 $\mathrm{CAI}$ 수 업을 받은 집단의 $\mathrm{CAI}$ 활용 수업 선호도는 $68 \%$ 로, 강의식 수업만 받았을 때 CAI 활용 수업에 대한 막연한 기대가 더 포 것으로 조사되었다. 그러나 (드림 8)에서와 같이 후 가지 수업을 모두 받은 후의 CAI 활용 수업의 선호도는 70\%로 나 타나 (드림 7)과 혼 차이가 없는 것으로 나타났다.

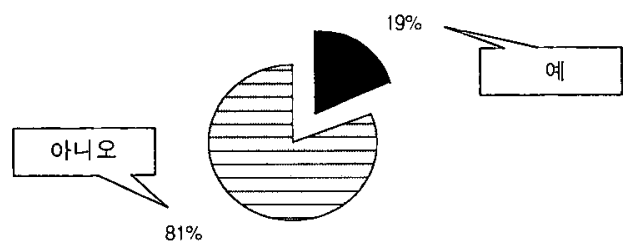

(그림 6) 강의식 수업이 학습에 효과가 있다? (설문A-2)

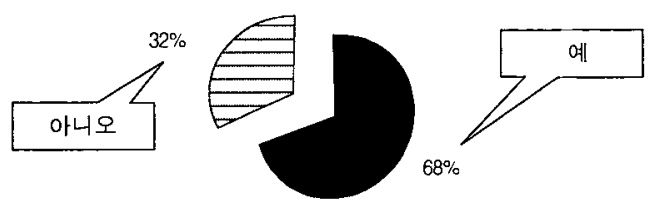

(그림 7) CAl 활용 수업이 학습에 효과가 있다? (설문B-2)

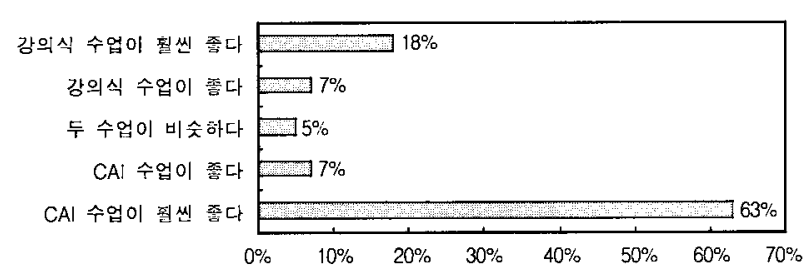

(그림 8) 어느 쪽 수업이 학습에 더 효과가 있는가 분포도 (설문C-1)

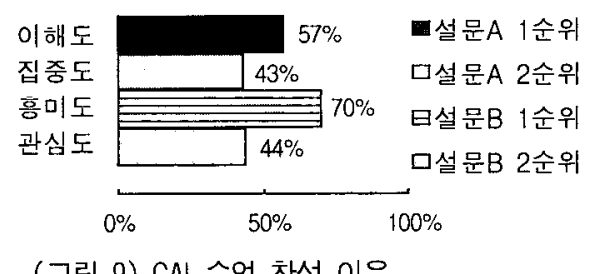

(그림 9) CAl 수업 찬성 이유

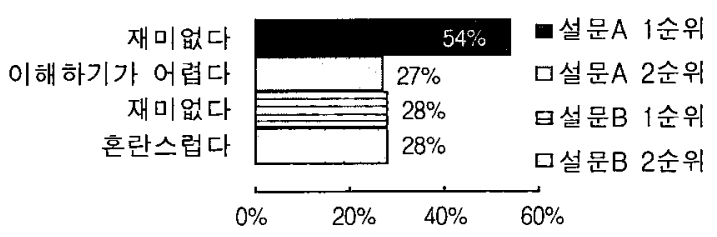

(그림 10) CAl 수업 반대 이유

뚜 가지 수업 방식의 학습 효과 분석은 (I릮 9)와 (I림 10) 과 같다. (디림 9)는 $\mathrm{CAI}$ 수업을 선호하는 학생둘을 들 대상으로 한 설문의 결과로, 강의식 수업만 반은 집단에서는 $\mathrm{CAI}$ 수업이 이해하기 쉬울 것이다가 $57 \%(17$ 명)로 가장 놀게 나타난 반면, 실제 CAI 수업을 밚은 집단에서는 재미있다가 $70 \%$ (18명)로 가
장 놇게 나타났다. 이는 $\mathrm{CAI}$ 수업의 기대치(이해하기 쉅다)와는 전혀 다른 분석 결과로, 실제 CAI 수업이 학생들에에 게 이해도보 다는 컴퓨터롤 사용한다는 그 자체만으로 흥미론 유발시키는 것 으로 분석되었다. 이는 $\mathrm{CAI}$ 수업의 실질적인 효과롤 반감시키는 것으로 분석된다. (그림 10)은 $\dot{\mathrm{CAI}}$ 수업을 선호하지 않은 학생 들을 대상으로 한 설문의 결과로, 강의식 수업을 받은 집단에서 는 재미없을 것이다가 $54 \%$ (4명)로 가장 녿게 나타난 반면, 실제 $\mathrm{CAI}$ 수업을 받은 집단에서는 재미없다 $28 \%$ (3명), 혼란스럽다 $28 \%$ (3녕)로 나타났다. 이는 CAI 수업을 선호하는 가장 콘 이유 (재미있다)와 CAI 수업을 선호하지 않는 가장 콘 이유(재미가 없다, 혼란스럽다)가 눅명하게 상반되어 나타났다.

뚜 수업을 모두 밚은 후, 강의식 수업을 선호하는 학생의 비율은 (드릮 8)에서 $25 \%$ 로 나타났다. 이든 학생들의 성적 분포도논른 정확히 분석하기 위하여 1 학기 중간고사 과학 성적 을 조사하였으며, 이의 결과는 <표 $5>$ 에서 제시한다.

〈표 5〉선호 수업에 따른 중간고사 성적 분포도

\begin{tabular}{|c|c|c|c|}
\hline 선호 수업 분하 & 비율 & 인원 & 중간도사 성적(인윈수) \\
\hline 강의식 수업 헤ㅇㅣㅣ닌 종나 & $18 \%$ & 13명 & $100(4), 97(4), 94(2), 91(2), 88(1)$ \\
\hline 강의식 수업이 쫑다 & $7 \%$ & 5 녕 & $97(1), 94(2), 91(1), 85(1)$ \\
\hline 두 수업이 비숫하다 & $5 \%$ & 4녕 & $97(1), 91(1), 88(1), 84(1)$ \\
\hline CAI 수업이 흥다 & $7 \%$ & 5명 & $91(1), 88(1), 85(1), 75(1), 70(1)$ \\
\hline CAI 수업이 헨씬 홓다 & $63 \%$ & 47 명 & $\begin{array}{l}100(2), 97(1), 94(1), 91(5), 88(4), \\
85(12), 84(1), 82(3), 81(1), 79(5), \\
78(1), 76(2), 75(1), 73(1), 70(1), \\
57(1), 55(1), 54(1), 51(1), 36(1), \\
33(1)\end{array}$ \\
\hline
\end{tabular}

<포 5>의 충간고사 성적에서 90 점 이상이 총 28 명으로 전 체의 $38 \%$ 이고, 이훈 학생 중에서 강의식 수업을 선호한 학생 이 16 명으로 $57 \%, \mathrm{CAI}$ 수업을 선호한 학생이 10명으로 $36 \%$ 이다. 전체 평균은 85.3점이며, 강의식 수업은 선호한 학생은 전원 상위 $50 \%$ 에 속하는 학생이었고, 하위 $50 \%$ 에 속하는 학 생들은 전원 $\mathrm{CAI}$ 수업을 선호하는 것으로 나타났다. 이 결과 는 성적이 우수한 학생일수녹 강의식 수업을 선호하는 경향 이 있는 것으로 분석되었다. 이는 굉장히 중요한 분석 결과로 앞으로 이에 대한 길은 연구가 요망된다. 따라서 멀티미디어 CAI 프로그램을 활용한 수업의 극대화롤 꾀할 수 있는 방안 으로 학생둘의 수준에 따론 수준변 수업을 진행한 경우, 하위 권 학생을 대상으로 하는 수업일 경우는 $\mathrm{CAI}$ 와 같은 멀티미 디어 자로롤 환용한 수업에 더 많은 비중을 두는 수업 방식 을, 상위륜 학생을 대상으로 하는 수업일 경우는 강의식 수업 에 더 많은 비충을 뚜되, 멀티미디어 자포둘운 조듬씩 활용하 는 수업 방식을 제안한다.

(그립 11)은 4가지 관접에서 강의식 수업과 CAI 수업 하 나만 밚았을 때의 상호 비표한 분석 결과로, 4 가지 관점에서 모두 CAI 활용 수업을 선호하는 것으로 나타났다. 틓히 CAI 환용 수업이 재미있다가 $81 \%$, 강의식 수업이 재미있다가 $8 \%$ 보다 월등히 놇은 것으로 가장 많은 격차가 나타났다. 두 비 윤의 합이 $100 \%$ 가 되지 않은 이유는 부응답 때문이다. 그리 
고 강의식 수업의 집중도는 예(24\%), 아니오(76\%)이고, CAI 활용 수업의 집중도가 예 $(49 \%)$, 아니오(51\%)로 나타났다. 이 결과에 따르면 CAI 타이틀을 학습에 활용 받은 집단이 그렇 지 않은 집단보다 이해도, 흥미도, 기억도는 높아졌으나 집중 도는 강의식 수업에 비하여 부분적으로 높아졌다고 핡 수 있다.

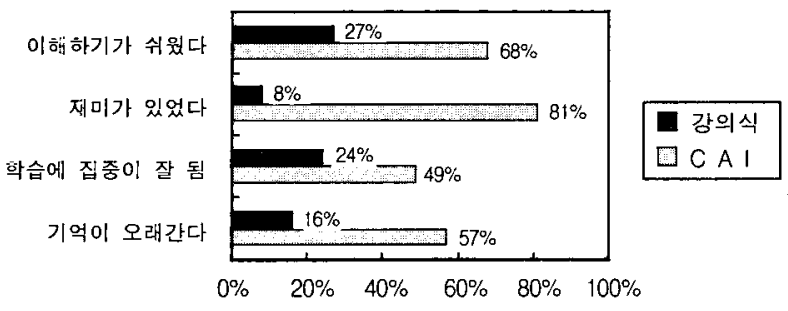

(그림 11) 강의식 수업과 $\mathrm{CAl}$ 수업만 받았을 때의 선호도 (설문 $\mathrm{A}-3,4,5,6$ 설문 $\mathrm{B}-3,4,5,6$ )

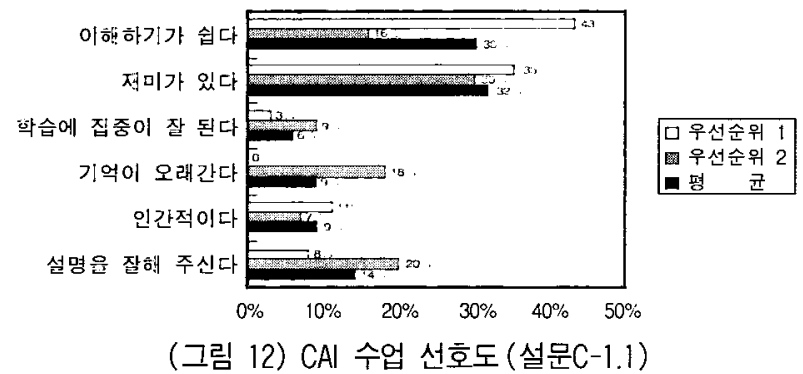

(그림 12)는 두 가지 수업을 모두 받은 후의 CAI 수업 선 호도의 분석 결과로, $\mathrm{CAI}$ 수업만 받았을 때 (그림 9)에서 $\mathrm{CAI}$ 선호도가 가장 높은 이유로 흥미도가 $70 \%$ 로 나타났으나, 두 수업을 모두 받은 후의 CAI 선호 이유는 (그림 12)에서 제시 된 것처럼 이해하기 쉅다가 $43 \%$ 로 나타나, 선호하는 이유가 바뀌었다. 이는 강의식 수업과 $\mathrm{CAI}$ 수업을 뜰 다 받은 후에 조사한 설문 $\mathrm{C}$ 의 결과가 더 정확하다 할 수 있으므로, 겨ㄹㅜㅜㄱ $\mathrm{CAI}$ 롤 활용한 수업의 가장 큰 기대치는 다양한 컨텐츠의 제퐁 으로 인한 수업의 이해도롤 높이는 것으로 결본지을 수 있다.

\section{2 .3 강의식과 $\mathrm{CAI}$ 수업 후의 설문 졀과 분석}

설문지 C는 학습자가 "심장과 혈액의 단원"을 한시간씩 CAI 활용 수업과 강의식 수업을 받은 후의 설문지이다. 위의 두 수 업을 모두 받고 난 후 두 가지 수업 방식을 비교하여 느끼 점 을 설문함으로써 $\mathrm{CAI}$ 활용 수업이 일반 강의식 수업 보다 실 제로 얼마나 효과가 있는지를 정확하게 분석하고자 하였다. 이 롫 위한 설문은 11 항목으로 ㅜㅜ성되어 있다.

(그림 13)과 (그림 14)의 결과 강의식 수업의 가장 큰 장점 으로 교사의 직접적인 설명으로 이해가 잘된다가 $72 \%$ (53명), 가장 큰 단점으로는 교사의 일방적인 수업 진행방식이 $77 \%$ (57명)로 나타났다. 이는 강의식 수업에서 표사에 관련된 부 분이 장점과 단점으로 동시에 나타났다. 따라서 수업 중 질문 시간의 배당 혹은 토론 학습과 같은 학생돌이 자율적으로 수 업에 참여할 수 있는 방안이 강의식 수업에서 반드시 필요한 것으로 생각된다.

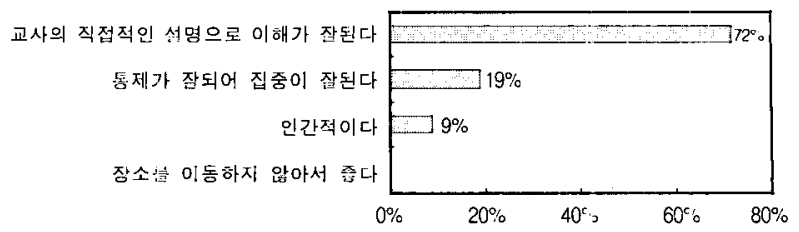

(그림 13) 강의식 수업의 장점 분포도

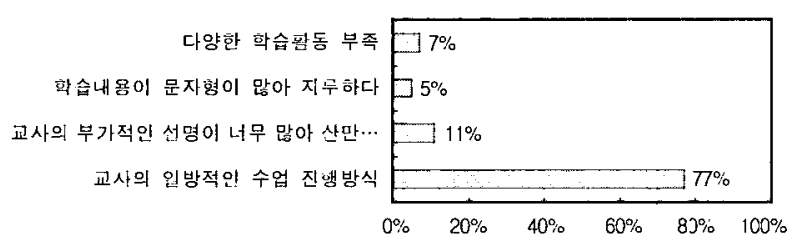

(그림 14) 강의식 수업의 단점 분포도

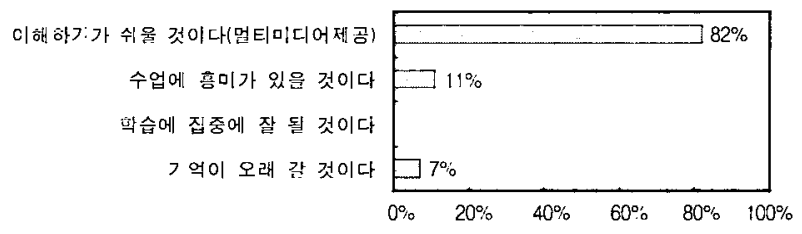

(그림 15) CAl 활용 수업의 장점 분포도

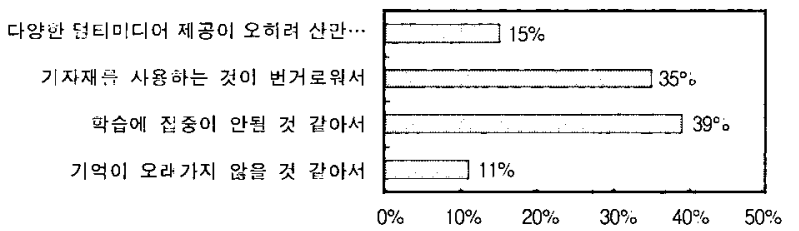

(그림 16) CAl 활용 수업의 단점 분포도

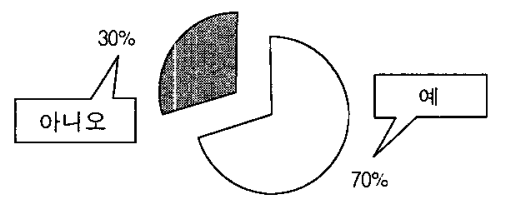

(그림 17) 두 수업을 모두 받은 후의 CAl 선호

( $=L$ 립 15)와 (드림 16)의 결과, $\mathrm{CAI}$ 활용 수업의 장점은 다 양한 멀티미디어의 제공으로 이해하기 쉽다 $82 \%(61$ 명), 단점 으로는 학습에 집중이 잗 안 된다 $39 \%$ (30명)와 기자재 사용 이 번거로.워서 $35 \%$ (22명)가 비슷한 분포로 나타났다. $\mathrm{CAI}$ 수업에서 학습 집중이 잘 안 된다라는 이유는 여러 가지로 추 정해 볼 수 있으며, 대표적인 것으로 수업의 고저(소리의 높 고 낮음, 중요한 부분의 강조 등)가 없이 화면간 쳐다브는 $\mathrm{CAI}$ 수업의 획인적인 진행 방식의 결과로 강의식 수업의 단점인 교사의 잃방적인 섭명과 같은 것으로 간주된다. 따리서 학생 이 어떤 형태로든 참여할 수 있는 방안이 CAI 햘용 수업에서 도 고려되어야 할 것으로 생각된다. 또한 CAI 프로그램이 조 잡하거나 복잡하고 어려운 내용으로 되어 있다면, 오히려 학 습하는 학생흘의 집중도롤 떨어뜨리는 결과롤 초래할 수도 있다. 니리고 기자재 사용이 번거롭다고 답한 것은 기자재의 관리 문제, 기자재 이동 문제 등이 복합적 요인으로 나타난 것 
으로 볼 수 있는데, 각 학교에서 수업에 사용되는 기자재의 효 율적인 관리가 학습에 충요한 역할을 하는 것으로 분석되었다.

(ㄴ리밈 17)의 셜과 둑 가지 수업을 보두 받은 후, CAI 홮용 수업을 밝고 신다가 $70 \%$ (52명), 강의식 수업을 받기 신다가 $30 \%$ (22명)로 나타났다. (- 2 림 8)에서 두 수업이 비숫하다라 고 응답한 학생이 꿀 중 하나만 선택하라는 설껀에서는 전보 강의식 수업을 선호한 것으로 분석되었다. 따라서 $30 \%$ 학생 이 CAI 환용 수업보다는 선생닙의 인간적인 감정이 있는 강 의식 수업을 반고 신다는 것과 <표 5>에서 세시된 것처런 이돌 학생의 성적 분포가 상위인 점은 $\mathrm{CAI}$ 수업의 가장 높은 선호드린인 이해하기 쉽다와 재미있다가 성적이 상위인 이들에 게는 별 의띠가 없음을 의미한다.

(ㄴ림 18)과 (느림 19)는 주 수업 방법 충 하나를 선택한 이유곱 이해도, 흥미드, 집중드, 기억드로 나'두어 비표해서 본 석한 것이다.

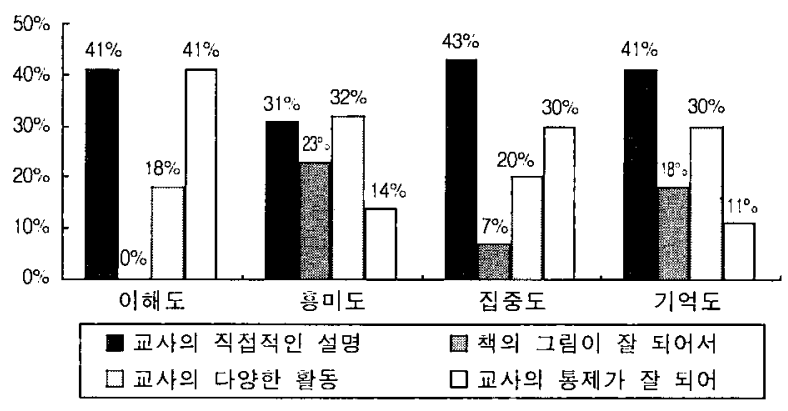

(그림 18) 강의식 수업

(이해도, 홍머도, 관심도, 기억도 비교 분석도)

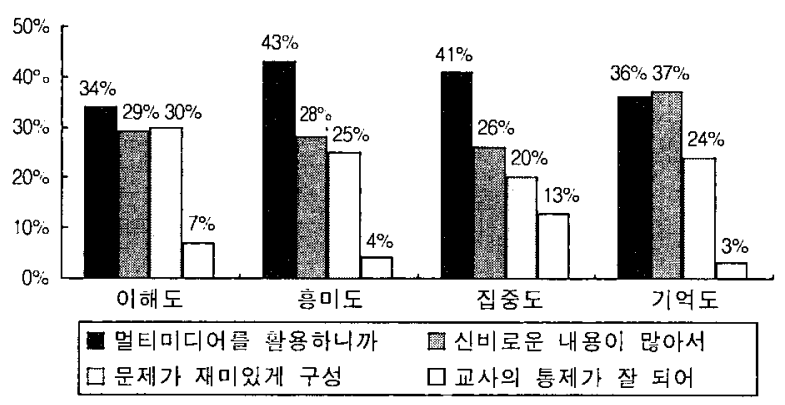

(그림 19) CAl 활용 수업

(이해도, 홍미도, 관심도, 기억도 비교 분석도)

(ㄴ릴 1ㅏㅁ에서 강의식 수업의 선호 이유는 이해도, 흥미드, 집충도, 기억도 보두에서 교사의 직접적인 설명이 가상 놇게 나타났다. 이는 기사의 다양한 경험과 환동음 바탕으롤 재미 있는 섬명이 학생든에 게 이해와 재띠, 관심과 기억은 향상 시

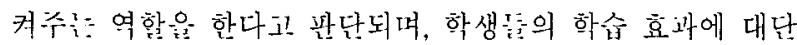
한 영향을 미치논 썻으로 본석되었다. ( 2 립 19)에서 CAI 선

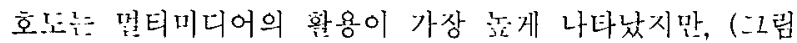
18)에 비해 나더지 항복도 상대적으로 다양하게 나타났다. 주 녹해 볼 사항은 기엄드에서 멀티비디어 활용과 신비로운 내 용이 많아서가 거의 같은 비유료로 나타났는데, 이는 동영상은
통한 교과서에 없논 새로운 내용이 흥미폰 유밭시키고 이것

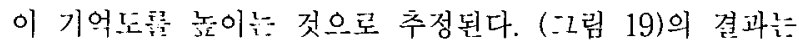
$\mathrm{CAI}$ 의 설계 시 고려해야 할 사항으로 간주된다.

(드림 20)의 결과 과학 수업에 CAI 타이릴을 활용한 수업 은 학습에 매우 도움이 된다가 $79 \%$ (58명)로 나타났다. 이는 맊 로써 설명이 곤란한 과학 과목과 같은 븍징을 가진 과목에 대해 특히 CAI 타이를의 활용이 매우 필요하다는 것을 의미한다.

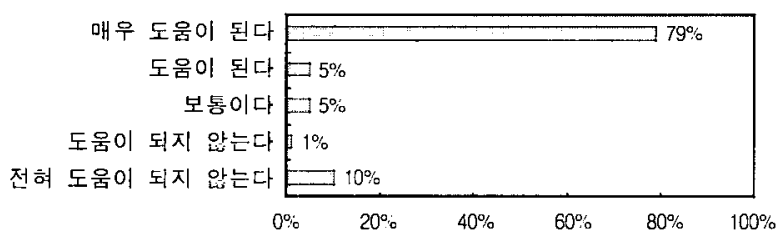

(그림 20) 과학 수업에 CAI 타이롤 활용이 학습에 도움이 된다

\section{5. 결 론}

지는까지 많은 CAI 타이훌이 다양하계 개발되어 왔으나, 현재까지 개밚된 CAI 프로니램의 학습 효과에 대한 실증적인 연구는 거의 이톧어지지 않았다. 따라서 번 연구는 CAI 프로 Z $L$ 랩의 학습 효과성은 검층하기 위한 방법으로 두 개의 또집 단을 선정하고 이릴 집단에 대해 본 연구에서 개밝한 CAI 포 포드랩울 직접 수업에 할용한 멇티미디어 CAI 수업과 일반 강의식 수업을 번잘아 푿번씩 진행한 후, 푸 수업 방법의 학 솝 효과에 비치는 영향을 평가지와 선둔시롤 통해 분석하는 방벏을 제시하였고, 느 결과 폰 분석하였다.

분석 결과, CAI 타이들을 활용한 반의 평관 점수는 70.81 이 고, 강의식 수업을 한 반의 평군 점수는 68.38로 나타나, 개인 지도형 벓티미디어 CAI 프로느랩을 학습에 활용한 수업이 $=1$ 렇지 않은 수업보다 학업 성취토가 약간 놇은 것으로 나타났 다. 하지만 좀 더 학습의 수준을 향상시킨 심화 학습에 대해서 는 강의식 수업이 $\mathrm{CAI}$ 수업보다 훨씬 효과석인 것으로 나타 났다. 이는 CAI 활용 수업이 흐ㅇㅔㅣ론 유밭시키고 전반적인 학

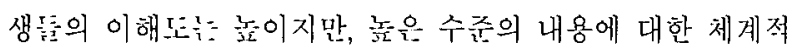
인 학습 방법으로는 다소 미합한 것으로 분석되었다. 기리료 $70 \%$ 의 학생이 CAI 수업을 선호하는 것으고 나타났지만, 강 의식 수업은 선호하는 나머지 $30 \%$ 의 학생 노누 성적이 상위 권에 속해, 수준별 훅은 능력별 교육 시에는 이러한 결과폴 고 려한 필요가 있는 것으로 분석되었다. 따라서 멃티미디어 CAI

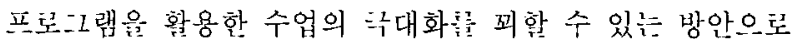
7차 교육과정에서 학생필의 수준에 따론 수순별 수업을 진행 한 경우, 하위권 학생을 대상으로 하는 수업은 CAI와 같은 멀 티비디어 자도론 활용한 수업에 더 많은 비쑹을 두는 수업 방 식을, 상위뀐 학생을 대상으로 하는 수업은- 강의식 수업에 더

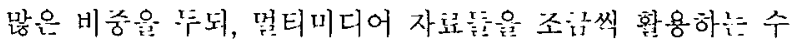
업 방식을 제안하였다.

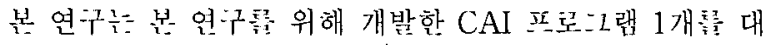

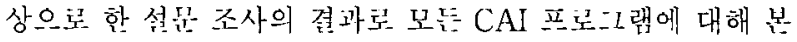


연구의 결과롤 그대로 적용하기는 다소 무리가 있을 거라 생 각된다. 따라서 앞으로 다양한 분야의 많은 CAI 프로그램과 더 많은 실험 집단을 대상으로 본 논문에서와 같은 실험을 행 하여 그 결과롤 도출할 필요성이 있다.

\section{참 고 문 헌}

[1] 교육부, 학교 컴퓨터 교육강화 방안, 한국교육개발원, 1998.

[2] 이태욱, 컴퓨터교육론, 좋은출판사, 1999.

[3] 나일주 - 정인성 공저, CAI 개발과 활용, 교육과학사, 1990.

[4] 백소영, 김 명, "수준벌 개별 학습을 지원하는 문제 은행 시스 템의 설계와 구현”, 한국컴퓨터교육학회논문지, 제 3 권 제 2 호, pp. $31-38,2000$.

[5] 노순호, 용환승, "원격 수학 교육을 위한 수식 대화 시스템의 설계 및 구현”, 한국컴퓨터교육학회논문지, 제 3 권 제 1 호, pp. 65-74, 2000.

[6] 서정민. “반복연습형 CAI에서 문항선택 전략이 사실적 정보 의 기억에 미치는 효과", 서울대학교 교육 대학원 석사학위논 문, 1996 .

[7] 유승안, 이재인, “수학과 도형 학습을 위한 온라인 역할 분담 게임의 설계”, 한국컴퓨터교육학회, 하계발표논문집, 2001.

[8] 이철현, 차재혁, 안미리, 이태욱, "절차적 시뮬레이션 기법을 적용한 중학교 컴퓨터 교과용 웹 코스웨어 개발”, 한국컴퓨터 교육학회논문지, 제4권 제2호, pp.1-12, 2001.

[9] 임유택, 정재열, "ARCS 학습동기화 모형을 적용한 영어 학 습 웹 코스웨어의 설계 및 구현", 한국컴퓨터교육 학회논문지, 제 3 권 제 2 호, pp.11-20, 2000.

[10] 이창하, 김송민, 김일곤, 박길흠, "학생과 교사의 상호 작용을 증가시키기 위한 원격 교육 시스템의 설계 및 구현", 한국정 보과학회논문지(C) 제 3 권 제5호, 1997.

[11] 장규화, 노영욱, "자기 주도적 학습 능력 신장을 위한 윕 기반 가상 수업 시스템의 설계 및 구현", 한국컴퓨터교육학희논문 지, 제3권 제1호, pp.161-168, 2000.

[12] 정상욱, 송태욱, 김태영, "컴퓨터 네트워크 학습을 위한 시뮨 래이션형 웹 코스웨어 설계 및 구현", 한국컴퓨터iㅛ육학회논 문자, 제 3 권 제2호, pp.39-46, 2000.

[13] 최숙영, "웹 상에서 정신 지체 학생의 수 개념 학습을 위한 멀티미디어 CAI 시스템", 한국컴퓨터 교육학회, 제 2 권 제 1 호, pp.146-154, 1999.

[14] 이재희, "개별화 학습을 위한 기하 영역의 WBI 설계 및 구 현”, 부경대학교 교육대학원 석사학위논문, 2001.

[15] 김정헌, "Java 서블릿 기반의 가상 강의 시스템 자동 구축 룰킷의 구현", 경성대학교 교육대학원 석사학위논문, 2000 ,

[16] 반송록, "중학교 식물의 종산 작용 실험에서 인터넷 가상 실 험실이 탐구 능력 신장에 미치는 효과", 서울대학교 교육 대학 원 생물전공 석사학위논문, 2000.

[17] 최정임, “웹 기반 수업에서 상호 작용 증진을 위한 교수 전략 탐구”, 교육공학연구, 제15권 제3호, pp.129 154, 1999.
[18] 송문석, “웹 기반 상업 부기 코스웨어 프로그램의 기발에 관 한 연 구”, 전남대학교 기-육대학원 상업교육전동 석사학위논문, 1998 .

[19] 박미정, "ICT㱸 활용한 가정과 Web 기반 문제 해결 학습 환 경의 개발 및 적용", 한국교원대학교 교육대학원 가정교육전 공 석사학위논문, 2001.

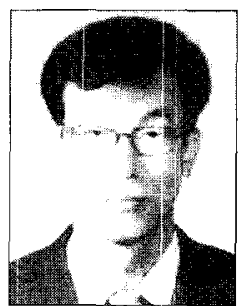

\section{조 해 곤}

e- mail : gongo@chollian.net 1987년 충남대학교 금속공학교육과 졸업 2001년 신라대학교 컴퓨터교육패(교육학석사) 1989년 현재 부산 망미중학교 교사 관심분야 : 컴퓨터교육, 원격 교육

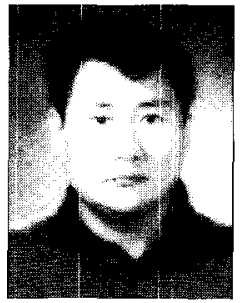

\section{정 재 열}

e-mail : jychung@silla.ackr 1989 계명대학교 전자계산학과 학사 1991 계명대학교 전자계산학과 석사 1991년 1994년 한국전자통신연구소 선임연 구원

1997 경북대학교 컴퓨터공학과 박사 1997년 현재 신라대학교 컴퓨터교유과 조교수 관심분야 : 컴퓨터교육, 이동통신, Ad Hoc 네트워크

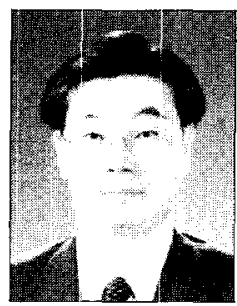

$$
\text { 노 영 욱 }
$$

e-mail : yulho@silla.ac.kr 1985년 부산대학교 계산통계학과 학사 1989년 부산대학교 계산통계학과(전산학전 공) 석사

1998년 부산대학교 전자계산학과 박사 1989년 - 1996년 한국전자통신연구원 연구원 1996년 현재 신라대학교 컴퓨터교육과 조피수 관심분야 : 컴뀨터기육, 운영체제, 멀티미디어, 병렬/분산시스템

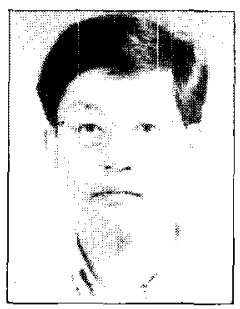

\section{최 재 혁}

e-mail : jhchoi@silla.ac.kr

1984년 경북대학교 전자공학과 컴퓨터공학 전공 학사

1986년 경북대학교 전자공학과 컴퓨터공학 전공 석사

1994년 경북대학교 전자공학과 컴퓨터공학 전공 박사

1989년 1994년 신라대학교 전자계산학과 조교수

1995년 — 현재 신라대학표 컴쀼터표육과 교수

관심본야 : 컴퓨터교육, 한국어정보처리 